\title{
ナイロン弾性体の合成
}

\begin{tabular}{|c|c|}
\hline $\begin{array}{l}\text { 京都付立大学女子短期大学部 } \\
\text { 京都工芸織維大学繊維学部 }\end{array}$ & 永田 奏 \\
\hline
\end{tabular}

\section{SYNTHESIS OF NYLON ELASTOMERS}

\author{
By Minoru Nagata*, Tsuyoshi Kiyotsukuri** and Norito Uchino** \\ * (Department of Clothing Sciemce, Junior Women's College of Kyoto \\ Prefectural University, Shimogamo, Sakyo-ku, Kyoto, Japan) \\ ** (Faculty of Textile Science, Kyoto University of Industrial Arts and \\ Textile Fibers, Matsugasaki, Sakyo-ku, Kyoto, Japan)
}

\begin{abstract}
Nylon elastomers composed of polyether as soft segment and nylon as hard segment were synthesized by the interfacial or low temperature solution polycondensation of polyether (polybutylene glycol or polyethylene glycol) with diacid chloride (sebacyl chloride or adipyl chloride) and diamine (hexamethylene diamine).

The reduced specific viscosities of polymers obtained by the interfacial method were remarkably higher than those of polymers obtained by the low temperature solution method. The polyether/nylon compositions of polymers estimated by the IR method coincided satisfactorily with those calculated from the monomer ratio. The melting point depressions of polymers with increasing polyether content were smaller than those of random copolymers calculated by Flory's equation when the chain length of polyether was shorter and were larger than those when the chain length of polyether was longer.
\end{abstract}

(Received September 5, 1976)

\section{1. 緒言}

熟可塑性弾性体の開発が最近各方面で活発に行なわれ でり”、ポリウレタンやポリェステル系の熱可塑性弾 性体などがすでに商品化されている。周知のとおり，熱 可塑性弾性体は弾性挙動を示すンフトセグンントと、物 理的架橋の役割を果たすハードセグメントとからなって いる。本研究のナイロン弾性体は、ハードセクメントに ナイロン、ソフトセダメントにポリェーテルを用いたブ ロック共重合体であるが，これについては特許 に部 記載がみられる程度で詳細な報告はなされていない。ナ イロンはポリェステルとともに合成繊維として重要な地 位を占めているだけに，経済的にも有利に製造しうるポ リマーであり，種類も豊富である。そこでこのナイロン をハードセグメントに用いた熱可塑性弾性体の合成につ いて以下に報告する。
2. 実 驗 法

2.1 合成経路

用いた合成経路を下記する。

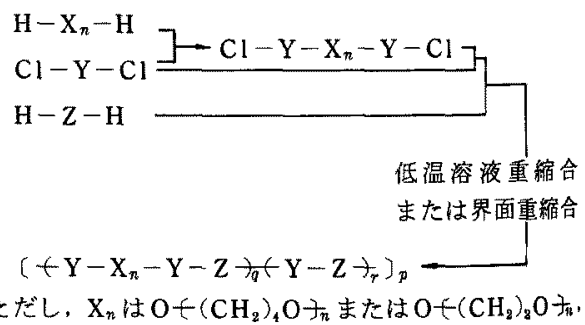
$\mathrm{Y}$ はOC $\left(\mathrm{CH}_{2}\right)_{8} \mathrm{CO}$ まはOC $\left(\mathrm{CH}_{2}\right)_{4} \mathrm{CO}, \mathrm{Z}$ は $\mathrm{HN}\left(\mathrm{CH}_{2}\right)_{6}$ NHである。

すなわち，まずポリブチレングリコール(PBG)(分 子量 1089 または 1968) またはポりエチレンダリコール (PEG)(分子量 1000）をナイロンの酸成分であるた六 
シン酸または7ジピン酸の酸クロリドと反応させて、ポ リエーテルのシ酸クロリドを調製し、これにさらに鎖長 讀節のための所定量の酸クロリドを加えて、へキサメ手レ ソジフンと低温溶夜重縮合法または界面重縮合法によ り反応させて，一連のポリェーテルノナイロンブロック 共重合体を合成した。

\section{2 単暴体の調製}

アジピン酸クロりド执よ゙せバシン酸クロリドは，そ れぞれアジピン酸とセバシン酸を塩化チオニルと反応さ せて常法により調製し、減王烝留により精製した。一キ サィチレンジランンは乾蜗した後蒸留した。ポリエーテ ルは市販品を十分乾燥して用いた。

ポリエーテルのジ酸クロリドの合成は, 所定量のポリ エーテルを重縮合のための容媒に溶解し，脱本のためそ の約 $1 / 5$ 量を减王留去した後, 所定量の酸クロリドを 加え，塩化水素がスの発生が止をまで窒素がスを通じて かきまぜることにより行ない，これに所定の組成比にな るようにさらに酸クロリドを加えて次の重縮合に用いた。

\section{3 重縮合法}

界面重縮合は，著者らが先にナイロンの界面共重縮合

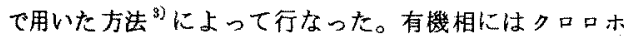
ルムを用い，酸クロリド濃度を $1.0 \mathrm{~mol} / l$ とした。水相 のジミン濃度は $0.1 \mathrm{~mol} /$ ととし，これに酸受容体の水 酸ナトリウムを $0.2 \mathrm{~mol} / l$ 加えた。有機相の酸クロリド と水相のジランをモル比 $1: 1$ で涺合して, ホモシナイ ザー中で $5 \sim 10^{\circ} \mathrm{C}$ で $5 \mathrm{~min}$ 急速にかきまぜた。重合物は ガラスフィルターで洰别し, 水でよく洗浄した後減圧乾 嬠した。

低温容夜重箱合は, 容媒に ジオキンを用い，酸クロり ド濃度を $0.4 \mathrm{~mol} / l$,ジアミ ン濃度を $0.8 \mathrm{~mol} /$ とし、酸 クロリトとシアミンのモル比 を1：2としてホモシナイザー 中で $5 \sim 10^{\circ} \mathrm{C}$ で $5 \mathrm{~min}$ 急速に 加きまぜることにより行ない， タタノールに投入して重合物 を析出させた。

\section{4 溶液粘度測定法}

ウペローデ型粘度計を用い， 試料 $0.05 \mathrm{~g}$ をハタクレゾール $10 \mathrm{ml}$ に溶解して $30^{\circ} \mathrm{C} て ゙$ 遗 元比粘度 $\left(\eta_{\mathrm{sp}} / 0\right)$ 測定した。

2.5 赤外吸収スペクト ル測定法

試料 $2 \mathrm{mg}$ を臭化カリウム
$200 \mathrm{mg}$ と渥合し，加开鏔剂成形して，島津自記分光光 度計 IR-27C型を用いて湘定した。

\section{6 融点測定法}

柳本式微量融点測定装珇MP-S 3 型を用いて, 熱板儒 光顕徽鏡下で測定した。なお，一部の試料については島 津示差熱分析装置 DT-2B型による测定も行なったが， 上記の方法により决定した融点と同一の傎が得られた。

\section{3. 結果と考察}

\section{1 重樎合法の比較}

低温溶液重樎合法拉よび界面重縮合法による合成結果 を表1に示寸。PEGを用いた殇合にはぐースト状のも のが得られ，重合物の乾蜗が非常に困難であったが。 PBGを用いた場合には容易に粉末状の重合物が得られ た。重合物の逻元比粘度估低温溶液重縮合法によるもの と比較して界面重縮合法によるもののほうが顕著に高く， 高分子量の共重合体を製造しらることが判明した。この 原因は，界面重䨂合法では塩基性の強い水酸化ナトリウ ム索酸受容体として用いているためと考えられる。なお 共重合体が生成していることは，ポリエーテルがクロロ ホルムに可溶であるのに対し，この共重合体が不溶とな ることから確顶した。

ポリエーテルノナイロンプロック共重合体の合成法上 しては，本研究で用いた酸クロリドを用いる溶液重縮合 法よりもナイロン塩を用いる溶融重合法によるほうが経 済的に有利であると考えられ，著者らはこの方法による 合成をまず検討してみたが，ポリエーテルとナイロンは

Table 1 Synthesis of polyether-nylon block copolymers.

\begin{tabular}{|c|c|c|c|c|c|c|}
\hline $\begin{array}{l}\text { Sample } \\
\text { No. }\end{array}$ & polyether & nylon & $\begin{array}{c}\text { Method of } \\
\text { polycondensation }\end{array}$ & $\begin{array}{c}\text { Composition } \\
\text { polyether/nylon } \\
(\text { wt } \%)\end{array}$ & $\begin{array}{l}\text { Yield } \\
(\%)\end{array}$ & $\begin{array}{l}\eta_{\mathrm{sp}} / C \\
(\mathrm{~d} 1 / \mathrm{g})\end{array}$ \\
\hline $\begin{array}{l}1 \\
2\end{array}$ & $\begin{array}{c}\text { PEG } \\
\text { MW } 1000\end{array}$ & N610 & $\begin{array}{l}\text { Low temperature } \\
\text { solution }\end{array}$ & $\begin{array}{l}75 / 25 \\
60 / 40\end{array}$ & - & $\begin{array}{l}0.86 \\
0.60\end{array}$ \\
\hline $\begin{array}{l}3 \\
4 \\
5 \\
6 \\
7\end{array}$ & $\begin{array}{c}\text { PBG } \\
\text { MW } 1089\end{array}$ & N6 10 & $\begin{array}{l}\text { Low temperature } \\
\text { solution }\end{array}$ & $\begin{array}{l}25 / 75 \\
33 / 67 \\
50 / 50 \\
67 / 33 \\
73 / 27\end{array}$ & $\begin{array}{l}69.8 \\
77.0 \\
86.1 \\
69.4 \\
72.3\end{array}$ & $\begin{array}{l}0.46 \\
0.48 \\
0.65 \\
0.63 \\
0.65\end{array}$ \\
\hline $\begin{array}{r}8 \\
9 \\
10\end{array}$ & $\begin{array}{c}\text { PBG } \\
\text { MW } 1089\end{array}$ & N610 & Interfacial & $\begin{array}{l}25 / 75 \\
50 / 50 \\
65 / 35\end{array}$ & $\begin{array}{l}75.9 \\
78.7 \\
83.6\end{array}$ & $\begin{array}{l}1.10 \\
1.00 \\
0.93\end{array}$ \\
\hline $\begin{array}{l}11 \\
12 \\
13\end{array}$ & $\begin{array}{c}\text { PBG } \\
\text { MW } 1968\end{array}$ & N610 & Interfacial & $\begin{array}{l}25 / 75 \\
50 / 50 \\
65 / 35\end{array}$ & $\begin{array}{l}84.7 \\
88.1 \\
57.4 \\
\end{array}$ & $\begin{array}{l}1.29 \\
1.00 \\
1.55\end{array}$ \\
\hline $\begin{array}{l}14 \\
15 \\
16\end{array}$ & $\begin{array}{c}\text { PBG } \\
\text { MW } 1089\end{array}$ & N66 & Interfacial & $\begin{array}{l}25 / 75 \\
50 / 50 \\
65 / 35\end{array}$ & $\begin{array}{l}81.8 \\
80.0 \\
50.0\end{array}$ & $\begin{array}{l}1.20 \\
0.95 \\
1.24\end{array}$ \\
\hline 17 & PBG MW 1968 & N66 & Interfacial & $50 / 50$ & 76.0 & 1.52 \\
\hline
\end{tabular}


相容性が悪いために溶融時に 2 相分触を起こし，良好な ブロック其重合体は得られなかった。

\section{2 共重合体の組成分析}

表Iに示した組成は用いた単量体の比率から計算した 值であるが，重合物の収率が $100 \%$ ではないな，単量 体組成と重合体組成が相違する愁念がある。そこで著者 らが先にナイロンの界面共重縮合物の分析に用いた方法 ${ }^{3)}$ に準じて，赤外吸取スベクト儿法による組成分析を行な った。

PBGとN610扣よび両者の等重量淈合物の 1385 $1250 \mathrm{~cm}^{-1}$ の赤外吸収スペクトルを图1に示す。 $\mathrm{N} 610$ の $1250 \mathrm{~cm}^{-1}$ の吸光度 $\left(h_{1}\right)$ と PBGの $1385 \mathrm{~cm}^{-1}$ の吸光 度 $\left(h_{2}\right)$ に着目し，一連の組成を変化させた湿合物を調

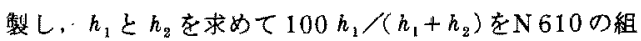
成に㞶してプロットし，図 2 の検量曲線を得た。これを 利用して重合物の組成分析を行なった結果を表 2 に示す。 計算値と测定值はかなり良好に一致している。

界面重縮合法を用いて合成したナイロン共重合体の組 成分析に関しては，N66-26系，N66-6I 系などにつ
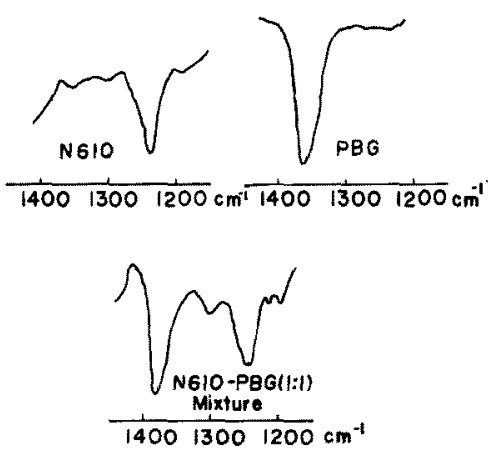

Fig. 1 IR spectra of homopolymers and 1:1 mixture.

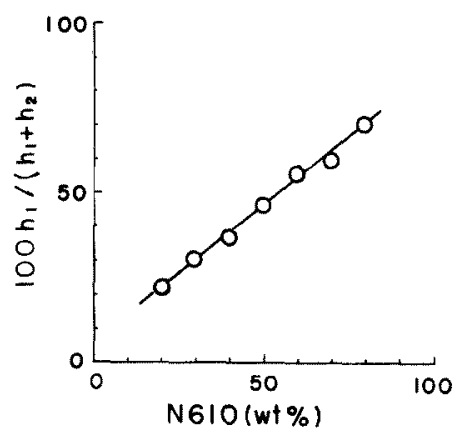

Fig. 2 IR calibration curve of N610-PBG mixtures.
Table 2 IR Analysis of polyether-nylon block copolymers.

\begin{tabular}{c|c|c|c}
\hline Sample & \multirow{2}{*}{$\begin{array}{c}\text { Method of } \\
\text { No. }\end{array}$} & \multicolumn{2}{|c}{ Composition } \\
polycondensation & \multicolumn{2}{c}{$\begin{array}{c}\text { polyether/nylon (wt\%) } \\
\text { calcd. }\end{array}$} & observed \\
\hline 8 & & $25 / 75$ & $27 / 73$ \\
9 & Interfacial & $50 / 50$ & $49 / 51$ \\
10 & & $65 / 35$ & $63 / 37$ \\
\hline 3 & & $25 / 75$ & $23 / 77$ \\
4 & Low temperature & $50 / 50$ & $45 / 55$ \\
5 & solution & $67 / 33$ & $71 / 29$ \\
\hline
\end{tabular}

いての報告")があり，単量体組成と共重合体組成との間 に影著な相違が認められた。著者らもN 66-610手》, $\mathrm{N} 26-210$ 系 $^{5)}$, N 210-610 系 ${ }^{8}$ について類似の結果 を得た。この原因は，共重合成分の 2 種の酸ク口りトの 加水分解性の相違に㷌せられる゙〜る)。

本研究においても，重合物の収率が 100 吼にならない 原因として、酸クロリドが加水分解したことが挙げられ よう。ただし, 本研究においては共重合成分のポリエー テルのジ酸クロリドとナイロンの酸クロリドは同じ酸ク ロリドであり，赤外分析による測定值が計算值とほぼ一 致したことから，酸クロリドの加水分解や重縮合に対す る反応性が、酸っロリドの分子の長さに偖存しないこ上 が示㖫される。著者らは，同様の現象をPET-N 610 系ブロック共重合体の界面重縮合法による合成において も見出している6)。

\section{3 共重合体の锅点}

共重合体の融点と組成(重量市)との関係を図3に示 す。ソフトセダメントのポリエーテルの鎖長 (分子量) が同じ場合には、ポリエーテルの重量かが大きいほど融 点は低下する傾问が認められる。また同じ重量かではポ リエーテルの鎖長が長いほうが融点は低い。

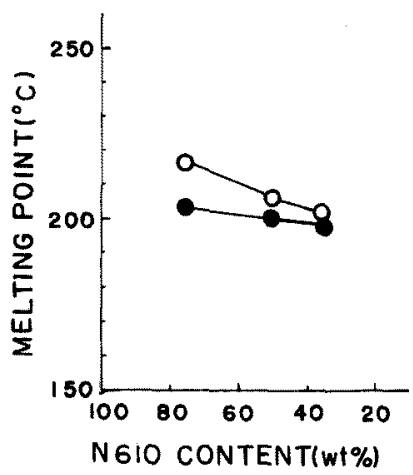

Fig. 3 Melting point of N610-PBG block copolymers.

O : PBG MW 1089

- : PBG MW 1968 


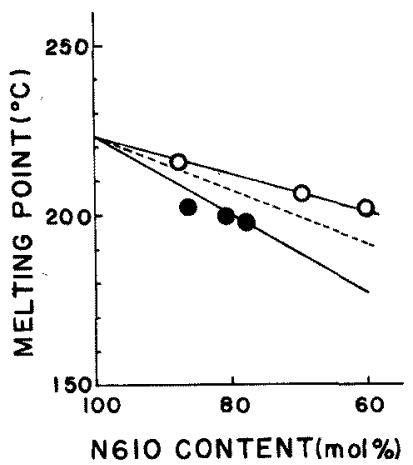

Fig. 4 Melting point depressions of N610-PBG block copolymers.
O : PBG MW 1089
- :PBG MW 1968
: Flory random copolymer

图4にはモルタに換算した組成と融点の関俰を示す。 またランダム共重合体に関する Floryの融点降下式を用 い, N610の融解熱を $7300 \mathrm{cal} / \mathrm{mol}^{\text {s) }}$ として計算した N 610 を主成分とするランダム共重合体の融点降下曲線 应，图中に点線で示す。重合物の融点降下はFlory曲線 にかなり近似しているが，ポりエーテル鎖長が短い場合 にはそ扎よも高く，長い場合にはそれよりも低くなっ ており住目される。

界面重椎合法を用いて共重合体を合成する場合には， 単量体や反応中間体の反応性や反応場所への移動速度の 相違のために，ブロック共重合体が生成することが報告
されているき。著者らは，そのブロック連鎖長が溶媒に より相違することを見出した ${ }^{9}$ が，本研究で使用したク 口ロホルムは比較的ランダム共重合体に近い構造を与え る溶媒である。しかし，PBGのMW=1089の重合物は 融点降下がFlory 曲線より少なく，したがって主成分の N 610 の連鎖長がランダム共重合のそれよりも長いブロ ック共重合体を形成していることが推定される。この原 因としてポリェーテルとN 610 との相容性が覀いこと に起因する反応の不均一性が挙げられよう。一方PBG のW $=1968$ の重合物の融点はFlory曲線よりも低下 しており特翼的である。この原因は，ポリエーテルが希

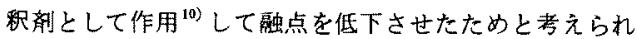
るが，この作用がポリエーテルの鎖長が大になることに より顕著になったものと思われる。

\section{文献}

1) たとえば, 頁本 操, 今中 弘；繊学誌, $30, \mathrm{P}-$ 366 (1974)

2) Du Pont; USP 3044987 (1962)

3) 清造 剛, 金谷彰郎; 高分子化学, 28，279(1971)

4) V.V. コルシャック著. 稲葉弥之助他共訳；「高分子 合成化学」，朝倉書店，p.144（1967）

5) 清造 㓮, 馬昜 巧, 西川恵清; 高分子化学, 30 , 587 (1973)

6) 清造 剛, 下村泰志; 高分子化学, 28，516(1971)

7) P. J. Flory; J. Chem. Phys., 17, 223 (1949)

8) L.E. Nielsen; "Mechanical Properties of Polymers", Reinhold Publishing Corp., P 34 (1962)

9) B. Ke, A.W. Sisko; J. Polymer Sci, 50, 87 (1961)

10) M. Inoue; $J$. Polymer Sci, A1, 3427 (1963) 